vertical, corresponding to the margin of the quadratus lumborum, extending from the upper edge of the last rib to the iliac crest. Tumours containing fluid may be always reduced in size by tapping before being removed, and a large suppurating kidney should be drained before nephrectomy is undertaken. Experience has shown that the ureter, however thickened, causes no trouble, and may be left in the wound secured with a simple catgut ligature. The stitching of this to the surface must add a danger both immediate and remote. One speaker referred to a kidney so adherent that he thought it would be impossible to remove it from the loin. I believe a kidney, however adherent, may always be so removed, if the capsule be left behind. There is a patient leaving Guy's Hospital to-day quite well, whose left kidney I removed about five weeks ago. It had been suppurating for nine years, and was closely adherent to the colon and surrounding structures. To have removed it together with the capsule would have been certain death, but it was stripped out without much difficulty from within the capsule. I have now removed five kidneys in succession through the loin without a death, and this success depends not on the operator, but on the operation (which, speaking generally, should almost always be lumbar), and on a proper selection of cases suitable. I am, Sirs, your obedient servant,

R. Clement LuCAS, B.S., F.R.C.S. Senior Assistant Surgeon to Guy's Hospital.

Finsbury-square, Nov, 28th, 1887.

\section{CHIAN TURPENTINE AND CANCER.} To the Editors of THE LANCET.

Sins,--It is now some seven years ago since Professor Clay gave to the profession, through the medium of your journal, the welcome intelligence that at last a specific cure for cancer had been found in Chian turpentine; and I think it may without fear of contradiction be asserted that no remedy has had a fairer trial at the hands of his confrères or more grievously disappointed them. It is true that Mr. Clay endeavoured to get over the discrepancy by alleging the impurity of the drug used, but doubtless many like myself still continued their observations with the genuine article as supplied by Southall of Birmingham, to find the result still the same.

Notwithstanding the almost unanimous condemnation of the treatment, I find in a later paper of Mr. Clay's (THE LANCET, vol. ii. 1881 , p. 1033) these words: "An enlarged experience, however, has confirmed the statements made in my original paper, and I have now the satisfaction of being able to declare that I have nothing to withdraw or to qualify as regards the statements $I$ then made as the result of observation as to the effects of Chian turpentine in uterine cancer." From time to time he has favoured his professional brethren with repeated cures of cancer by this remedy, and even so recently as in your last week's issue three more examples are given. But what about the failures? In the interest of the public at large, such claims as Mr. Clay makes for Chian turpentine ought not to pass unchallenged by those who differ from him. Unfortunately, examples of cancerous disease are only too common upon whom this remedy (supplied, if necessary, by his own chemist) might be tested by a tribunal in whom the profession at large would have confidence, and the doubt once and for all resolved. If this drug came out of the ordeal triumphantly, then I feel sure there would not be a single dissentient to Mr. Clay occupying a position not inferior to Jenner or Harvey as one of the greatest benefactors of our species; but it, on the contrary, it is wholly useless as a remedy, then let it drop into a well-merited, and not too premature, oblivion. I am, Sirs, yours truly,

Nottingham, Nov. 21st, 1887. GKORGE ELDER.

\section{THE FELLOWSHIP OF THE ROYAL COLLEGE} OF SURGEONS.

To the Editors of THE LANCET.

SIRs,-With your permission I should like to say a few words in reply to Mr. Holmes' sweeping condemnation of the power possessed by the Council of Surgeons of electing to the Fellowship Members of twenty years' standing, two in each year. If as many as that, or more, should present claims arising from the work done during that twenty years, which claims are open to the investigation and criticism of the Council, I think it would be out of all reason to reject them on the ground of there having been no examination. How many of the Fellows who have gained their position in the only way Mr. Holmes would recognise, and have not been engaged in teaching or lecturing, would be able to retain it if, after twenty years of active practice, they were asked to undergo a second, similar to that which gave them their qualification? In my own case, the twenty years were spent in active and successful practice as a hospital surgeon, and though so many things practically useless were probably forgotten that an examination would have been difficult to pass, I yet believed that on assuming the position of consulting surgeon to the same institution I should not be asking too much in seeking to be recognised as a Fellow. So, I presume, thought the six gentlemen who, as already Fellows, signed my application. I believe in my own year mine was the only application, and I do not think these have ever been very numerous. But if they were to seek the honour, and were to present the same testimonials, 1 do not think the status of the Fellows would be so lowered by granting it, as Mr. Holmes seems to think.

I am, Sirs, your obedient servant,
Dec. 1st. 1887.

PHARMACEUTICAL WEIGHTS AND MEASURES. To the Editors of THE LANCET.

Sins,-Since the introduction of the cental system (which, it may be surmised, is a step towards the future decimal system) into the Pharmacopoia, our weights and measures for surgery use have become troublesomely obsolete, so much so that it is with difficulty that the general practitioner who dispenses his own medicines can now do so without great waste of valuable time and much mental labour, in having to reduce his drachms and ounces to minims or grains. Solutions that were formerly prepared as so much per drachm or ounce, have become now so much per cent. It is a matter of surprise that the vendors of our weights and measures have not been sufficiently alive to the wants and requirements of the times, and sufficiently enterprising to supply a demand which is now seriously felt, for weights marked in grains, and measures in minims, in grades of tens and hundreds, instead of the old-fashioned and now virtually obsolete scruples and drachms, and fluid drachms with their halves. I would suggest that weights be now made according to the following gradation: $1,2,3,4,5,10,15,20,25,30,40,50,60,100,250$, and 500 ; that minim measures be graduated on the left hand in drachms and half-drachms, and on the right hand be marked in grades of 10 minims up to 200 , the first 100 having intermediate or 5-minim lines; that ounce measures be graduated on the left in ounces and half-ounces, the first half-ounce being subdivided into drachms, the second into two drachms; and on the right in 25,50 , and 100 minims; and that half-pint measures be graduated on the left in halfounces and ounces, and on the right in grades of 100 minims. Some recognition of the old system, it is obvious, should be retained, and, although only recommended above for fluid measures, the requirements being greater, might also be adopted for the $n e w$ weights ; for instance, the $20 \mathrm{gr}$. weight might be stamped on the obverse side with the old symbol, $\mathrm{Bj}$; the $30 \mathrm{gr} ., 3 \mathrm{ss}$; the $40 \mathrm{gr}$., $\Rightarrow \mathrm{ij}$, and the $60 \mathrm{gr}$., $3 \mathrm{j}$.

Were the above weights and measures possible to be obtained, and supplied through the ordinary channels, the labour and mental calculation saved to the busy practition would be immense.

Dovercourt, Nov. 1887

I am, Sirs, yours truly,

\section{THE PREVENTION OF PUERPERAL SEPTIC AEMIA.}

\section{To the Editors of THE LANCET.}

SrRs,-An ounce of fact is worth a ton of theory, gaseous or sagacious, Here is a single fact. It occurred in connexion with the case of extra-uterine gestation-a note regarding which appeared a fortnight ago, and also to-day in your columns. There could be no doubt as to "septic 
infection" (whatever the phrase stands for) being derivable from this patient, as she was septicæmic from decomposition of the placenta before its entire separation from the sac.

The next point is, that at one of the dressings, after separation had fairly begun, I removed, partly with dressing forceps partly with my fingers, a considerable piece of the decomposing placenta. My fingers were malodorous, showing their skin to have been soaked with microorganism excrement and decomposition products, even after washing with a solution of perchloride of mercury, of moderate strength, in the room.

On going home I found a message from a midwife, asking me to help a case over for her with the forceps. I purified my hands in the course of about three minutes by using (1) soap and warm water with the nail-brush; (2) remembering how the stench of uterine cervical cancer is got rid of from the examining finger by turpentine, I washed my hands with turpentine, using the saturated nail-brush, then more soap and water, and tinally rinsing in a solution of iodine. I washed my hands and instruments at the patient's in iodised hot water, and used fresh carbolic oil for lubrication. The patient, a multipara, got up, I am informed, as I did not require to see her after delivery, on the celebrated "ninth day," and made a perfectly good recovery, being now quite well.

Acase of this kind (my own cases also at the time were nonsepticæmic), where a good deal of vaginal manipulation took place, and where the fingers were, not half an hour before, in a septic state, answers various questions. It is not a merely providential escape from the production of what is pedantically and euphemistically termed "heterogenetic" septicœmia. "Rash !" some who have been wittily described as baving "passed the climacteric," and so are unchanging in their views, will exclaim. I reject the imputation, for 1 have faith founded on fact in appropriate antisepticism properly performed.

I am, Sirs, your obedient servant, ARChibatd D. MaCdONALD, M.D. Edin. Iiverpool, Nov. 28th, 1887 .

\section{ELECTION OF ASSESSUR IN THE UNIVERSITY OF ST. ANDREWS.}

To the Editors of THE LANCEx.

SIRs,-I trust you will permit me to appeal to my fellowgraductes of this University in support of the candidature of Dr. John Duncan as the Assessor in the contest now going on. The high position which this gentleman holds, whether regard be had for his professional or his academic distinction, eminently qualifies him for the post, added to which, being on the spot, he will be enabled to attend all the University coure meetings, which it will be wholly out of the power of his opponent, Viscount Cross, to do, as must be well known. I am, Sirz, yours obediently, JOSEPH ROGERS.

Montague-place, Russell-square, London, Nov. 30th, 1887.

\section{"IS CANOER CONTAGIOUS?"} To the Editors of THE LANCET.

SIRS,-I have been looking over my "Cause of Death Certificates" from March, 1883 , to present date, and if you think the following cases, which have happened in my own practice, worth a corner in your valuable journal, I should like to bring them before the notice of the profession, as I think they might perhaps interest some of your many readers:-
E. G., aged 51
H. H., aged 58 ...
Cancer of breast
J. D., aged 54 Cancer of breast Cancer of testicle and stomach
H. C., aged 56 G. W.B.,aged 66 ...
M. D., aged 55
T. C., aged 48
G. T., aged 71 Cancer of uterus Cancer of rectum Cancer of uterus Cancer of tongue Cancer of rectum \{ Cancer of vagina and uterus Cancer of breast
E. J., azed 58
Cancer of stomach
... March, 1883 ... July, 1883 . ... Oct., 1884. .. March, 1885 . ... Oct., 1885.
... Jan, 1886. . Aug., 1886. .. March, 1887. ... April, 1887. May, 1887. ... Sept., $188 \%$.

The disch rges from some of these cases were incessan and extrmely offensive, in spite of the utmost cleanliness, and not only the rags, but the houses were saturated with what I may perhaps be allowed to call "cancer smell," strong carbolic acid lotion and other disinfectants being constantly necessary to enable the inmates to remain with the patient. In each of my cases, husbands, relatives, and nurses are all at the present time in perfect health. Some of them certainly complained occasionally of the smell going down their throats and "settling on their stomachs," as they called it, which was not surprising; but these symptoms readily yielded, at my suggestion, to a strong glass of brandy-and-water.

As there are always two sides to every question, would it not be well to collect evidence if we can, and see on which side the balance in favour of or against the contagion theory lies? I am, Sirs, yours faithfully,

Bury St. Edmunds, Nov. 28th, 1887 .

\section{To the Editors of THE LANCET.}

SIRS,-In a thesis written for the M.D. (Camb.) degree in June last, I made reference to the above subject; and, in support of my belief that malignant diseases are contagious, not only by immediate contact as mentioned by Sir Peter Eade, but also in a wider sense, I ventured to record the following, which occurred in my practice about two years ago: In a fen district, nine miles from any town or railway, and three from the nearest village, and with very few $d$ wellings in it, three labouring men, all beyond middle age, living at separate houses and working together on the same farm, were each the subject of malignant disease within a comparatively fe w weeks of one another. Two of them had malignant disease of the stomach, and died at their own homes, the third had malignant disease of the oesophagus, and died at University College Hospital, where he was sent for surgical treatment. In the same thesis I wrote of the possible part played by the lymphatic system in the reception and ultimate development of the particular cell or cell products, which probably is the form the contagious material takes.

I am, Sirs, yours faithfully,

Wy. Groom, M.D. Cantab., \&c.

Wisbech, Nov. 17th, 1887

\section{NORTHERN COUNTIES NOTES. (From our own Correspondent.)}

A NEOICAL MAYOR FOR DURHAM.

Mr. W. C. BLACEETT, a general practitioner in the ancient and cathedral city of Durham, has been elected Mayor. Mr. Blackett was apprenticed to the late Dr. Green of Durham, and is an old pupil at St. Thomas's. While assistant to Dr. Green, in 1849, during the cholera epidemic he rendered exceptional services in many places in the county of Durham. He afterwards settled in practice in Durham, and entered the municipal body, having previously pledged himself to keep aloof from all cliques and parties. After twelve years service he left the Council, and at the end of nine years went back again. Then he retired to avoid the turmoil of a contest at a time when small-pox was prevalent, in order to prevent the spread of the disease. Mr. Blackett, who is in the prime of life, has reached now every honour in the power of his city to bestow, being Alderman, Justice of the Peace, as well as honorary Surgeon-Major to the 4th Durham Rifles. $\mathrm{He}$ is a keen sportsman and supporter of all manly games, such as cricket, quoits, football, boating, and swimming, as well as a benefactor to all local friendly societies.

$$
\text { FEBRILE EPIDEMIC IN THE NORTH. }
$$

For the last month an epidemic of a peculiar nature, whether as regards its frequency or some of its symptoms, has prevailed here. The patients are generally adults, taken ill, as a rule, with a rigor or slight chill; this is followed by feverishness and headache (the latter often severe), suggesting typhus. There is very little cough, and but trifing mucous irritation. Constipation is always present, and the high temperature continues for nearly a week. Muscular pains are complained of, and the head symptoms often include transient delirium. While the practiticner is porhaps considering what form of fever he has to deal with, the symptoms rather suduenly subside, but the convalescence is 